\title{
Pengaruh Lama Waktu Skarifikasi Terhadap Perkacambahan Biji Lamtoro Menggunakan Pupuk Organik Cair dari Limbah Isi Rumen Sapi
}

\author{
Influence of Scarification Time to the Germination of Lamtoro Seeds Used by Fertilizer \\ from the Liquid Organic Wastes of Cattle Rumen Contents
}

\author{
Muh. Rajabatari Gau*, Khaerani Kiramang, Muhamad Nur Hidayat \\ Jurusan Ilmu Peternakan, Fakultas Sains dan Teknologi \\ Universitas Islam Negeri Alauddin Makassar \\ *Korespondensi Email : muh. gau@gmail.com
}

\begin{abstract}
ABSTRAK
Tujuan Penelitian ini yaitu untuk mengetahui pengaruh lama waktu skarifikasi terhadap perkecambahan biji lamtoro sebagai pakan ternak dengan menggunakan pupuk organik cair dari limbah isi rumen sapi. Metode Penelitian ini, yaitu menggunakan Rancangan Acak Lengkap (RAL) dengan 4 perlakuan dan 5 kali ulangan, dengan cara pengukuran persentase kecambah dan tinggi kecambah selama 2 minggu penanaman, pengukuran dengan menggunakan mistar. Perlakuan dalam penelitian ini yaitu, biji lamtoro tanpa melalui perendaman (P0), perendaman biji lamtoro kedalam pupuk organik cair isi rumen sapi selama 10 menit (P1), 20 menit (P2) dan 30 menit (P3). Hasil penelitian menunjukkan bahwa perlakuan berpepengaruh nyata $(\mathrm{P}<0,05)$ terhadap tinggi kecambah tetapi tidak berpengaruh terhadap persentase kecambah.
\end{abstract}

Kata kunci : Lamtoro, Skarifikasi, Pupuk Organik Cairan Rumen Sapi

\begin{abstract}
The purpose of this study was to study the relationship of the length of the scarification time to germination of lamtoro seeds as animal feed using organic fertilizers from waste contents of cattle rumen. This research method used a Completely Randomized Design (CRD) with 4 preparations and 5 replications, by calculating the percentage of sprouts and height of sprouts for 2 weeks of planting, measurement using a ruler. The treatments in this study were, lamtoro seeds without immersion (P0), lamtoro seeds through liquid organic fertilizer filled with cattle rumen for 10 minutes (P1), 20 minutes (P2) and 30 minutes (P3). The results showed facts that significantly affected $(\mathrm{P}<0.05)$ on the height of sprouts but not high on sprouts.
\end{abstract}

Key words : Lamtoro, Scarification, Liquid Rumen

\section{PENDAHULUAN}

Lamtoro (Leucaenaleucocephala) merupakan tanaman kacang-kacangan yang cepat tumbuh, berasal dari bagian selatan Mexico dan bagian utara Amerika Tengah dan saat ini telah menjadi tanaman yang dibudidayakan di daerah tropis. Saat tahun 1870 sampai 1980- 
an, lamtoro dianggap sebagai pohon ajaib (miracle tree) karena memiliki banyak manfaat. Tanaman ini digunakan sebagai bahan pakan, kayu bakar, pupuk hijau, pengontrol erosi, tanaman pelindung, furniture, bahan pembuat kertas serta sebagai pangan untuk manusia. Lamtoro (Leucaenaleucocephala) merupakan leguminosa yang bernilai gizi tinggi sangat berpotensi digunakan untuk pakan ternak, karena percabangan yang kecil dan banyak serta daunnya disenangi ternak. Palatabilitas dan daya cerna daun lamtoro cukup tinggi. Keberadaan zat anti nutrisi dalam tanaman ini menjadikan pemanfaatannya sebagai pakan ternak perlu dibatasi penggunaannya. Kandungan nutrisi dari tepung daun lamtoro yaitu air 7,76 gr, abu 6,90 gr, lemak 3,34 gr, 14.10 gr, SK 19,60 gr, karbohidrat 28,30 gr dan energi (Widodo, 2010).

Kulit biji lamtoro yang keras, tebal, dan berlilin yang menyebabkan pembibitan kurang sempurna sehingga tanaman itu tumbuhnya tidak merata. Untuk mengatasi hal tersebut, maka dilakukannya perendaman dengan pupuk organik cair isi rumen dan skarifikasi kimiawi untuk melunakkan kulit biji lamtoro. Karena didalam isi rumen terdapat kandungan unsur hara seperti Nitrogen, Fosfor dan Kalium. Kemudian untuk mendapatkan hasil yang maksimal harus melalui proses fermentasi terlebih dahulu untuk membantu pertumbuhan pada tanaman.

Beberapa unsur hara yang terkandung dalam pupuk organik lebih sedikit daripada pupuk anorganik. Namun penggunaan pupuk dari bahan alami yang dilakukan secara kontiunitas dapat membuat struktur tanah menjadi lebih baik disbanding menggunakan pupuk anorganik. Pupuk organik mampu meningkatkan kemampuan tanah mengikat air, meningkatkan daya tahan tanah terhadap erosi, memperbaiki biodiversitas dan kesehatan tanah, serta mengurangi penggunaan pupuk anorganik. Selain itu, pupuk organik tidak akan menyebabkan residu pada hasil tanaman sehingga aman bagi lingkungan dan kesehatan manusia (Musnamar, 2003).

Limbah yang dihasilkan Rumah Pemotongan Hewan (RPH) yakni isi rumen yang bisa digunakan sebagai bahan baku dalam pembuatan pupuk cair yang alami. Limbah ini diperoleh dari saluran pencernaan ternak yang tidak dicerna secara sempurna. Penggunaan isi rumen menjadi bahan baku pupuk dapat mengurangi pencemaran yang ada di sekitar RPH. Akan tetapi, penggunaan limbah RPH masih kurang dimanfaatkan dan diolah menjadi pupuk cair, padahal dengan pengolahan menjadi pupuk cair limbah RPH tersebut dapat membuat daya simpan menjadi lebih lama dan efisien. Pupuk organic cair ini merupakan 
pupuk yang yang tidak padat dan mamput meresap ke dalam tanah bersama dengan unsurunsur hara yang dapat meningkatkan kesuburan tanah. Pupuk yang bentuknya cair jika terlalu banyak dalam tanah maka secara otomatis tanaman tidak akan sulit mengatur pemupukan dan kapasitasnya lebih merata, sehingg tidak akan terjadi penumpukan konsentrasi pupuk hanya pada satu tempat (Slamet dkk, 2005). Berdasarkan pernyataan tersebut maka perlu dilakukan penelitian tentang pengaruh skarifikasi terhadap perkecambahan biji lamtoro (Leucaena Leucocephala) dengan menggunakan isi rumen sapi.

\section{METODE PENELITIAN}

\section{Jenis dan Lokasi Penelitian}

Penelitian ini telah dilaksanakan selama 2 minggu bertempat di Laboratorium Pakan Terpadu, Jurusan Ilmu Peternakan, Fakultas Sains dan Teknologi, Universitas Islam Negeri Alauddin Makassar, Samata Gowa.

\section{Sumber dan Metode Pengumpulan Data}

\section{Tahap persiapan}

Langkah awal yang harus dilakukan sebelum melakukan penelitian ini adalah tahap persiapan yaitu pengumpulan biji lamtoro yang sudah masak berwarna cokelat diambil dari pohon dan didiamkan selama 7 hari sebelum dilakukan perlakuan, pengumpulan biji setelah 7 hari sebelum penanaman dipilih karena pada hari ketujuh biji yang matang sudah benarbenar kering dan sudah maksimal untuk di lakukan perbanyakan. Biji lamtoro yang digunakan berasal dari satu pohon yang sama (homogen) dan bagian biji yang di ambil adalah yang terdapat pada bagian tengah deretan biji.

\section{Tahap pelaksanaan}

a. Penyortiran biji lamtoro

Kualitas biji dapat diketahui melalui penyortiran, salah satu teknik penyortiran adalah dengan merendam biji pada air, sehingga dapat diketahui biji yang berkualitas baik dan kurang baik. Biji yang tenggelam dikategorikan sebagai biji yang berkualitas baik dan bernas (berisi). Timbang biji lamtoro yang digunakan.

b. Perendaman biji lamtoro kedalam pupuk organik cair isi rumen

Biji lamtoro yang telah melalui penyortiran kemudian selanjutnya dipindahkan kewadah perendaman pupuk organik cair, biji lamtoro direndam dengan menggunakan 
waktu yang berbeda dengan lama perenedaman 10 menit, 20 menit, 30 menit. Cairan rumen yang digunaan dari isi perut ternak ruminansia.

c. Penanaman biji lamtoro kedalam polybag

Setelah melalui perendaman dengan pemberian waktu yang berbeda, biji lamtoro tersebut akan dipindahkan kedalam polybag yang berisi tanah, pasir, kompos. polybag akan diisi masing-masing 5 biji lamtoro dengan menggunakan pingset, polybag yang telah diisi biji lamtoro kemudian akan disimpan pada tempat berteduh yang tidak terkena sinar matahari panas, apa bila polybag mulai mengering kita dapat meneteskan air kedalam polybag tersebut. Pemberian air kedalam polybag bertujuan untuk membantu pertumbuhan benih biji lamtoro.

Parameter yang diamati pada penelitian ini adalah persentase kecambah panjang akar dan batang dari biji lamtoro setelah 2 minggu perkecambahan. Adapun tinggi kecambah dilakukan pengukuran dengan mistar. Hasil yang didapatkan selanjutnya diolah secara statistik dengan menggunakan rancangan acak lengkap (RAL) dengan 4 perlakuan dan 5 ulangan dan apabila berpengaruh nyata maka akan dilakukan uji BNT (Beda Nyata Terendah) untuk melihat perbedaan terhadap variabel yang diamati.

\section{HASIL DAN PEMBAHASAN}

Hasil pengukuran perkecambahan hijauan pakan ternak biji lamtoro setelah 2 minggu penanaman yang mencakup persentase kecambah dan tinggi kecambah disajikan pada tabel dibawah ini:

Tabel 1. Hasil pengukuran rata-rata persentase kecambah dan tinggi kecambah biji lamtoro setelah 2 minggu penanaman.

\begin{tabular}{ccc}
\hline \multirow{2}{*}{ Perlakuan } & \multicolumn{2}{c}{ Parameter } \\
& Persentase kecambah $(\%)$ & Tinggi kecambah $(\mathrm{cm})$ \\
\hline P0 & 25 & $3,0^{\mathrm{a}}$ \\
P1 & 45 & $6,37^{\mathrm{b}}$ \\
P2 & 50 & $10,2^{\mathrm{b}}$ \\
P3 & 25 & $6,3^{\mathrm{b}}$ \\
\hline
\end{tabular}

Keteranagan: Huruf yang berbeda pada kolom yang sama menunjukkan perlakuan berbeda nyata $(\mathrm{P}<0,05)$ pada persentase kecambah dan tinggi kecambah.

\section{Persentase Kecambah}

Berdasarkan hasil sidik ragam perlakuan penambahan dengan pupuk organik cair isi rumen tidak berpengaruh nyata $(\mathrm{P}>0,05)$ terhadap perkecambahan. Apabila melihat hasil 
yang diperoleh pada analisis statistiknya tidak berpengaruh, tetapi secara rataan terlihat adanya kecenderungan peningkatan persentase kecambah Hasil penelitinan pada Tabel 1. Berdasarkan persentase kecambah menunjukkan bahwa P0 25\%, P1 45\%, P2 50\%, P3 25\%. Hal ini menunjukkan bahwa kandungan nitrogen, fosfor, dan kalium pada pupuk organik cair isi rumen berpengaruh pada pertumbuhan perkecambahan biji lamtoro namun tidak maksimal. Hal ini sesuai dengan pendapat Widodo (2010), yaitu bahan organik merupakan sumber energi dan makanan bagi mikroorganisme tanah yang dapat meningkatkan populasinya. meningkatnya mikroba di dalam tanah dapat juga menyebabkan laju dekomposisi bahan organik tersebut meningkat sehingga dapat menyebabkan siklus hara ketersediaan hara, serta permukaan pori mikro dan makro tanah dapat menjadi lebih baik. Proses Pemberian konsentrasi pupuk organik cair isi rumen sapi berpengaruh terhadap sifat biologi tanah dalam mengaktifkan pertumbuhan mikroba tanah, sehingga populasi mikroba menjadi meningkat yang mengakibatkan laju dekomposisi bahan organik semakin meningkat. Unsur hara yang tersedia dalam jumlah yang seimbang dapat membuat pertumbuhan tanaman, pembesaran dan pemanjangan sel akan berlangsung cepat sehingga beberapa organ tanaman tumbuh cepat sehingga mampu membentuk organ-organ pertumbuhan diantaranya titik tumbuh dan digunakan dalam pembentukan daun. Hal ini di dukung oleh Sinuraya (2015), unsur hara nitrogen, fosfor, dan kalium yang terkandung di dalam pupuk organik cair isi rumen sapi dapat tersedia bagi tanaman tetapi harus mengalami proses dekomposisi terlebih dahulu di dalam tanah serta membantu mengikat unsur-unsur yang ada di dalam tanah agar tidak mudah tercuci oleh aliran air dan dapat diserap dengan baik oleh tanaman.

\section{Tinggi Kecambah}

Berdasrkan hasil analisis variasi perlakuan penambahan dengan pupuk organik cair isi rumen berpengaruh nyata $(\mathrm{P}<0,05)$ terhadap perkecambahan. Hasil penelitinan pada Tabel 1. Berdasarkan persentase kecambah menunjukkan bahwa P0 3,0 cm, P1 6,37 cm, P2 10,2cm, P3 6,3 cm. tinggi kecambah pada P0 yaitu 3,0 cm dengan selama 2 minggu, Pada P0 tidak menggunakan perlakuan sehingga dinyatakan pertumbuhan tidak maksimal karna tinggi yang dihasilkan berbeda dengan menggunakan perlakuan. Pada tinggi kecambah P1 yaitu 6,37 cm dengan menggunakan perlakuan perendaman selama waktu 10 menit dan selama 2 minggu hasil belum maksimal karena perendaman biji lamtoro terlalu singkat sehingga penyerapan pupuk organik cair belum menembus bagian dalam yang merangsang 
perkecambahan biji lamtoro. Kemudian pada P2 yaitu 10,2 cm dengan menggunakan perlakuan perndaman selama waktu 20 menit dan selama 2 minggu dinyatakan sangat berpengaru karna perendaman dengan waktu 20 menit dapat membantu memaksimalkan penyerapan dengan baik sehingga memudahkan perangsangan laju tumbuhnya biji lamtoro. Pada P3 yaitu 6,3 cm dengan menggunakan perlakuan perendaman selama waktu 30 menit dan waktu selama 2 minggu perkecambahan, pada perkecambahan dinyatakan tidak baik dalam waktu 30 menit untuk melakukan perendaman sehingga pada pemataan dormansi pada biji kurang maksimal, Hasil tersebut didukung oleh pendapat Suyatmi dkk (2011), yang menyatakan bahwa setiap jenis biji dari berbagai tanaman mempunyai tingkat kekerasan kulit biji yang berbeda, hal ini mempengaruhi kepekaan kulit biji terhadap air dalam proses perkecambahan. Keadaan kulit biji yang keras seringkali menyebabkan biji mengalami penundaan perkecambahan walaupun sebenarnya benih tersebut tidak mati. Biji yang mempunyai sifat tersebut harus diberikan perlakuan awal untuk mematahkan fase dormansi.

\section{KESIMPULAN}

Berdasarkan hasil penbahasan tentang pengaruh lama waktu skarifikasi terhadap perkecambahan biji lamtoro disimpulkan bahwa pada perlakuan P2 berpengaruh nayata $(\mathrm{P}<0,05)$ terhadap persentase kecambah dan tinggi kecambah biji lamtoro (leucaena leucocephala) karena pada perlakuan P2 rata-rata persentase dan tinggi kecambah diperoleh nilai paling tinggi. Berdasrkan kesimpulan diatas waktu perendaman selama 20 menit dapat diaplikasikan oleh petani pembudidaya pakan ternak lamtoro (Leucaena leucocephala) karena persentase dan tinggi kecambah diperoleh paling baik.

\section{DAFTAR PUSTAKA}

Widodo, W. 2010. Nutrisi dan Pakan Unggas Konstektual. Universitas Muhammadiyah Malang. Malang.

Musnamar. 2003. Pupuk Organik Cair dan Padat. Penebar Swadaya. Jakarta.

Slamet, R., Arbianti., dan Daryanto. 2005. Pengolahan Limbah Organik (Fenol) Dan Logam Berat (Cr6+ Atau Pt4+) Secara Simultan Dengan Fotokatalis $\mathrm{TiO}_{2}, \mathrm{ZnO}-\mathrm{TiO}_{2}$, DAN CdS-TiO 2. Jurnal Makara Teknologi.

Sinuraya, M. A., Barus, A., dan Hasanah, Y. 2015. Respons Pertumbuhan Dan Produksi Kedelai (Glycine max (L.) Meriil) Terhadap Konsentrasi Dan Cara Pemberian Pupuk Organik Cair. Jurnal Agroekoteknologi . Vol.4 (1) 
Suyatmi,. Hastuti, E. D., dan Darmanti, S. 2011. Pengaruh Lama Perendaman dan Konsentrasi Asam Sulfat (H2SO4) terhadap Perkecambahan Benih Jati, Jurnal, Laboratorium Biologi Struktur dan Fungsi Tumbuhan Jurusan Biologi Fakultas. MIPA, UNDIP. 